\title{
The Effects of Oxidation States and Spin States of Chromium Interaction with Sargassum Sp.: A Spectroscopic and Density Functional Theoretical Study
}

\author{
Mohammad Abdul Matin 1*\#, Md. Aftab Ali Shaikh², Md. Anwar Hossain ${ }^{3 \#, ~ M d . ~ A l a u d d i n ", ~}$ \\ Tapas Debnath", Mohammed Abdul Aziz ${ }^{4}$
}

${ }^{1}$ Centre for Advanced Research in Sciences (CARS), Dhaka University, Dhaka, Bangladesh

${ }^{2}$ Department of Chemistry, Dhaka University, Dhaka, Bangladesh

${ }^{3}$ National University, Gazipur, Bangladesh

${ }^{4}$ Department of Theoretical and Computational Chemistry, Dhaka University, Dhaka, Bangladesh

Email: *matin123@du.ac.bd

How to cite this paper: Matin, M.A., Shaikh, Md.A.A., Hossain, Md.A., Alauddin, Md., Debnath, T. and Aziz, M.A. (2021) The Effects of Oxidation States and Spin States of Chromium Interaction with Sargassum Sp: A Spectroscopic and Density Functional Theoretical Study. Green and Sustainable Chemistry, 11, 125-141.

https://doi.org/10.4236/gsc.2021.114011

Received: September 29, 2021

Accepted: November 14, 2021

Published: November 17, 2021

Copyright $\odot 2021$ by author(s) and Scientific Research Publishing Inc. This work is licensed under the Creative Commons Attribution International License (CC BY 4.0).

http://creativecommons.org/licenses/by/4.0/

\begin{abstract}
The study of various oxidation states of chromium with Sargassum $s p$. is of particular interest since hexavalent chromium is reduced to trivalent chromium in an aqueous solution. In this study, a systematic density functional theory (DFT) calculations were performed to study the interactions of transition metal chromium ion with different oxidation states and spin states with the Sargassum $s p$. decorated with carboxylate (acetate) at the wB97XD/6-311++ $\mathrm{G}(\mathrm{d}, \mathrm{p})$ level of theory. The structures and binding energies of chromium metal-carboxylate complexes at various oxidation states and spin states in gas phase were examined. The coordination strength of $\mathrm{Cr}(\mathrm{VI})$ with the acetate ligand was predominantly the strongest compared to the other oxidation states. Vibrational frequency analysis, for the homoleptic monomers of tris $\left[\mathrm{Cr}^{\mathrm{III}}(\mathrm{AC})_{3}\right]^{0}$ and $\left[\mathrm{Cr}^{\mathrm{VI}}(\mathrm{AC})_{3}\right]^{3+}$ complexes, illustrate good harmony with the experimental and theoretical calculated frequencies. Using the time-dependent DFT (TD-DFT) at the level of CAM-B3LYP/6-311++G(d,p), the vertical excitation energies were obtained. The stabilization energies derived using the second order perturbation theory, $E_{i j}^{(2)}$, of NBO analysis confirmed the greater charge transfer for the observed trends in the metal binding. The calculated binding energies $(\Delta \mathrm{E})$ and interactions energies $\Sigma E_{\mathrm{ij}}^{(2)}$ favor the formation of $\left[\mathrm{Cr}^{\mathrm{VI}}(\mathrm{AC})_{3}\right]^{3+}$ complexes. The findings of this study identify efficient electronic factors as major contributors to the metal binding affinities, with promising possibilities for the design of metal-ligand complexes and sensing of the metal ions.
\end{abstract}

*Corresponding author.

\#These two authors contributed equally to this work. 


\section{Keywords}

Transition Metal, Time Dependent Density Functional Theory, Binding

Energy, Spectroscopy, Electronic Properties and Homoleptic Coordinated

Complex

\section{Introduction}

The toxic heavy metal chromium subsists in aqueous waste streams has the oxidation states of -2 to +6 [1]. The particular oxidation state of a metal is reliant on many factors comprising $\mathrm{pH}$, redox potentials and kinetics. For chromium metal, thermodynamically, +3 and +2 are the most stable states, while in the environment, +3 and +6 oxidation states are the most common ones. The electronic configuration of the element chromium in the ground state is $3 \mathrm{~d}^{5} 4 \mathrm{~s}^{1}$, whereas the most prevalent states +3 and +6 , it is $3 \mathrm{~d}^{3} 4 \mathrm{~s}^{0}$ and $3 \mathrm{~d}^{\circ} 4 \mathrm{~s}^{\circ}$, respectively [1]. Pourbaix diagram [2] ( $\mathrm{pH}$ plotted against EB) shows the existence of predominant or stable species of +3 state, $\left(\mathrm{Cr}\left(\mathrm{H}_{2} \mathrm{O}\right)_{6}^{3+}\right)$ and +6 state $\left(\mathrm{CrO}_{4}^{2-}\right)$ at low and high $\mathrm{pH}$ respectively. At $\mathrm{pH}<1$, the $\mathrm{H}_{2} \mathrm{CrO}_{4}$ is predominant, while at the $\mathrm{pH} 2$ to 6, the $\mathrm{HCrO}_{4}^{-}$and $\mathrm{Cr}_{2} \mathrm{O}_{7}^{2-}$ anions prevail. The yellow ion $\mathrm{CrO}_{4}^{2-}$ exists at a $\mathrm{pH}>8$ only. The oxidation state of +4 is the most stable at high $\mathrm{pH}$. Especially in acid solution, the +4 oxidation state disproportionates easily to chromium (III) and chromium (VI) [3]. The Chromium species predominantly occurs in the environment at the trivalent and hexavalent state [4]. Sargassum sp., a brown seaweed which was decorated with electron donor groups carboxylates studied for the biosorption of $\mathrm{Cr}(\mathrm{VI})$ to reduce less toxic $\mathrm{Cr}(\mathrm{III})$ under acidic condition at $\mathrm{pH} 2$ [5]. Above a certain $\mathrm{pH}$ level, the carboxylic acid groups usually dissociate, which makes them very reactive [6].

$\mathrm{Cr}$ (III) carboxylates show a ridiculous structural diversity like simple dimers as well as high nuclearity clusters [7] [8] [9]. In catalytic and materials applications, $\mathrm{Cr}$ (III) carboxylates are utilized commercially [10]. In different manufacturing industries, patented commercial products containing $\mathrm{Cr}(\mathrm{III})$ are used. The carboxylates, oxides and hydroxyl moieties usually bridged with metal centres via the presence of water in the reaction system [11]. Alfred Werner as early as 1908, synthesized the chromium metal triangular complex, $\mathrm{Cr}_{3} \mathrm{O}\left(\mathrm{RCO}_{2}\right)_{6}\left(\mathrm{H}_{2} \mathrm{O}\right)^{3+}$ and its derivatives were used theoretically for molecular magnetic interactions [12] [13]. These trimeric species are usually known as "basic chromium carboxylates" [14]. Chromium (V) is also found in organic matter for example humus. In studies with various cell systems, starting with chromate $\left(\mathrm{CrO}_{4}\right)^{3-}$, chromium (V) has been shown to be present as an intermediate. Previously reported that $\mathrm{Cr}\left(\mathrm{O}_{2} \mathrm{C}_{3} \mathrm{H}_{7}\right)_{3}$ was produced by the reaction of chromium (VI) oxide with carboxylic acid anhydrides [15]. The compound however soluble in methanol and consists of non-equivalent carboxylate groups in the infrared (IR) spectra inconsistent with monomeric structure. A homoleptic, monomeric, neutral $\mathrm{Cr}$ (III) car- 
boxylate of tris(methacrylato) was synthesized under aqueous conditions [16].

The present study was particularly interested in the investigation of tris-chromium carboxylate complexes formation with different oxidation states, spin states and therefore, special focus will be placed on the interactions between carbox-ylate with chromium ion. Complexes with $\mathrm{Cr}^{0}\left(\mathrm{~d}^{6}, \mathrm{~S}=0\right), \mathrm{Cr}^{\mathrm{I}}\left(\mathrm{d}^{5}, \mathrm{~S}=1 / 2\right)$, $\mathrm{Cr}^{\mathrm{II}}\left(\mathrm{d}^{4}, \mathrm{~S}=1\right), \mathrm{Cr}^{\mathrm{III}}\left(\mathrm{d}^{3}, \mathrm{~S}=3 / 2\right), \mathrm{Cr}^{\mathrm{IV}}\left(\mathrm{d}^{2}, \mathrm{~S}=3\right), \mathrm{Cr}^{\mathrm{V}}\left(\mathrm{d}^{1}, \mathrm{~S}=2\right)$ and $\mathrm{Cr}^{\mathrm{VI}}\left(\mathrm{d}^{0}, \mathrm{~S}=\right.$ 1) were considered. Matin et al. also studied tris-Fe-catecholate complexes with different oxidation and spin states [17]. The structures and metal-ligand binding energies of the coordinated complexes were studied. Thus, based upon these considerations the present study was conducted to describe the interactions between chromium and carboxylic acid of biomass using computa-tional modeling technique DFT to compute the thermodynamics of the formation of $\mathrm{Cr}(\mathrm{III})$ and $\mathrm{Cr}(\mathrm{VI})$ acetate complexes.

Herein, we however systematically implemented a DFT study on the tris-chromium acetate $\left[\mathrm{Cr}(\mathrm{AC})_{3}\right]^{n}(n=-3$ to +3$)$ complexes with different oxidation and spin states in gas phase. For estimating the coordinated complex structures, binding of chromium to ligand and stability, molecular structure investigations can be a predictive tool. Moreover, we studied the binding energy between the carboxylate (AC) ions with chromium metal ion at different oxidation states. In addition, we studied the natural bond orbital (NBO) analysis [18] [19] on [Cr(AC) $\left.]_{3}\right]^{\mathrm{n}}$ complexes with $\mathrm{Cr}^{\mathrm{III}}$ and $\mathrm{Cr}^{\mathrm{VI}}$ oxidation states to predict the second-order interaction energies $E_{i j}^{(2)}$.

We calculated the energy gap between the highest occupied molecular orbital (HOMO) and the lowest unoccupied molecular orbital (LUMO) and was used to calculate the chemical indices, for example chemical hardness, $\eta$ [20] electronic chemical potential, $\mu$ [21] and global electrophilicity index, $\omega$ [22]. These outcomes support us to know the thermodynamic behavior of such systems as a function of the quantum chemistry chemical descriptors.

\section{Computational Methods}

We studied the tris acetate complexes of chromium $\left[\mathrm{Cr}(\mathrm{AC})_{3}\right]^{n}$ at different oxidation states $(\mathrm{n}=-3$ to +3$)$ and spin states (Figure 1$)$. The carboxylic acid group was considered as the deprotonated carboxylic acid. The geometries of the complexes were optimized using density functional theory (DFT) with the hybrid exchange correlation functional DFT/wB97XD [23] and a triple- $\zeta$ basis set $(6-311++G(d, p))[24][25]$ [26] in gas phase. DFT with the wB97XD hybrid functional as implemented in Gaussian16 [27] and Gauss View 6.0.8 was used for visualization of the optimized minimum energy structures and simulated the vibrational spectra. We checked the binding energies of $\mathrm{Cr}(\mathrm{III})$ at different spin states and high spin state(HS) was found to be the minimum energy state. Thus acetate was considered as a weak-field ligand and hence all the metal coordinated complexes were supposed to have high spin multiplicity. We also checked different oxidation states and spin states of these complexes. Normal mode 


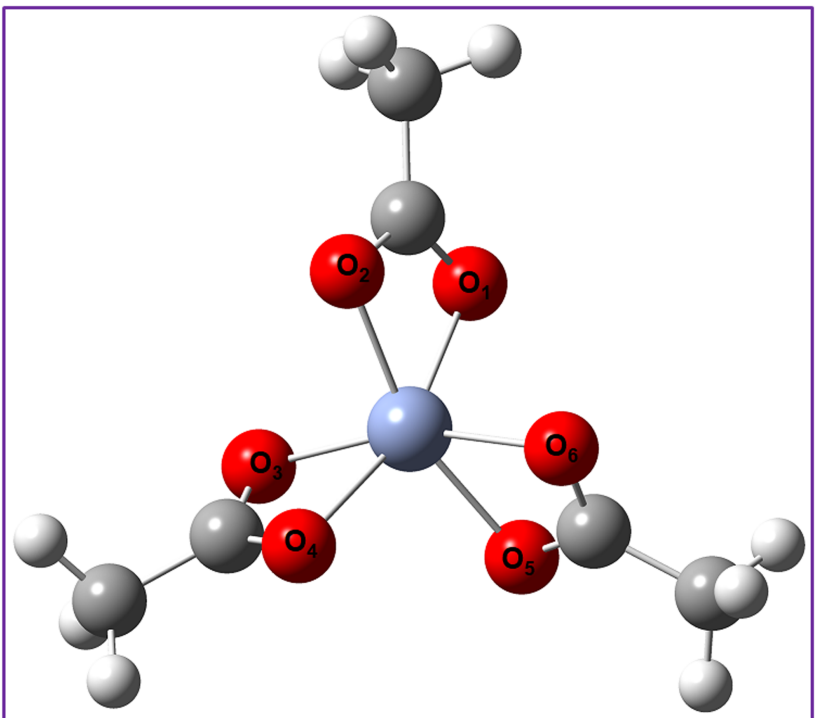

Figure 1. The optimized structure of tris-chromium acetate $\left[\mathrm{Cr}^{\mathrm{III}}\right.$ $\left.(\mathrm{AC})_{3}\right]^{0}$ complex.

coordinate analysis and no imaginary frequency confirmed the structure to be a minimum energy structure. The complexes were optimized without imposing any symmetry. After optimized the molecular geometry, the binding energies of the metal-ligand coordinated complexes were calculated as, [28]

$$
\Delta E=-\frac{E_{\text {complex }}-\left(E_{\text {metal }}+3 E_{\text {ligand }}\right)}{3}
$$

where, $E_{\text {complex }}, E_{\text {metal }}$ and $E_{\text {ligand }}$ are the energies of the tris $\left[\mathrm{Cr}(\mathrm{AC})_{3}\right]^{n}$ coordinated complexes, the metal ion and acetate ligand, correspondingly. Thus, $\Delta E$ states the binding energy per ligand. The complexes and ligand were optimized separately. Using the same level of theory at the optimized geometry of the tris $\left[\mathrm{Cr}(\mathrm{AC})_{3}\right]^{n}$ (where $n=0$ and +3 ) complexes, the infrared (IR) vibrational frequencies and intensities were calculated. The calculated vibrational wavenumbers were scaled using scaling factors 0.952 .

Electronically excited state calculations were carried out to compute the UV-Vis of the tris $\left[\mathrm{Cr}^{\mathrm{III}}(\mathrm{AC})_{3}\right]^{0}$ complex. Using the time-dependent density functional theory (TD-DFT) [29] at the level of CAM-B3LYP [30]/6-311++G(d,p) after the ground state geometry optimization, the vertical excitation energies were obtained.

The natural bond orbital (NBO) [18] [19] investigation was used for the electronic structures and chemical reactivity indices over the charge sharing of the atoms. NBO analysis was performed on the optimized structures to find out the electronic charges on the atoms and estimate the main donor-acceptor interactions

\section{Results and Discussion}

\subsection{Structural Analyses}

Figure 1 shows the monomeric, homoleptic optimized structure of tris-chromium 
$\mathrm{Cr}$ (III) and $\mathrm{Cr}(\mathrm{VI})$ carboxylate (acetate) complexes along with the ligand with numbering the atoms. The optimized molecular geometry parameters of the tris $\left[\mathrm{Cr}^{\mathrm{III}}(\mathrm{AC})_{3}\right]^{0}$ and $\left[\mathrm{Cr}_{\mathrm{VI}}(\mathrm{AC})_{3}\right]^{3+}$ complexes were reported in Table 1 which allied with $\mathrm{Cr}-\mathrm{O}$ and $\mathrm{C}-\mathrm{O}$ distances. As of tabulated data, a comparison between the bond length of free ligand and corresponding complexes of $\mathrm{Cr}(\mathrm{III})$ and $\mathrm{Cr}(\mathrm{VI})$ oxidation states were checked and found the $\mathrm{C}-\mathrm{O}$ bond length increased in the presence of metal ions [31] [32]. The calculated average $\mathrm{Cr}-\mathrm{O}$ bond lengths in the $\left[\mathrm{Cr}^{\mathrm{III}}(\mathrm{AC})_{3}\right]^{0}$ and $\left[\mathrm{Cr}_{\mathrm{VI}}(\mathrm{AC})_{3}\right]^{3+}$ complexes were $2.01 \AA$ and $1.85 \AA$ respectively whereas experimentally measured $\mathrm{Cr}^{\mathrm{III}}$-O bond length found $2.008 \AA$ [9]. The $<\mathrm{O}-\mathrm{C}-\mathrm{O}$ bond angle of free acetate $128.83^{\circ}$ were decreased to $116.83^{\circ}$ and $103.23^{\circ}$ of tris $\left[\mathrm{Cr}^{\mathrm{III}}(\mathrm{AC})_{3}\right]^{0}$ and tris $\left[\mathrm{Cr}^{\mathrm{VI}}(\mathrm{AC})_{3}\right]^{3+}$ complexes. On the other hand the angles of $\angle \mathrm{C}-\mathrm{C}-\mathrm{O}$ of free acetate $\left(115.18^{\circ}\right)$ increases to $121.58^{\circ}$ and $128.38^{\circ}$ of complexes $\left[\mathrm{Cr}^{\mathrm{III}}(\mathrm{AC})_{3}\right]^{0}$ and $\left[\mathrm{Cr}^{\mathrm{VI}}(\mathrm{AC})_{3}\right]^{3+}$ respectively [31] [32]. These decreases in bond lengths and bond angles were due to the ionic sizes of $\mathrm{Cr}(\mathrm{III})$ and $\mathrm{Cr}(\mathrm{VI})$ ions. These data indicates that $\mathrm{Cr}(\mathrm{VI})$ and carboxylate interaction is more stronger compare to $\mathrm{Cr}$ (III) metal ion. The geometry parameters are in fairly agrees well with the experimental data. The DFT optimized $\left[\mathrm{Cr}^{\mathrm{III}}(\mathrm{AC})_{3}\right]^{0}$ complex demonstrates several exciting features (Figure 1). The three carboxylate (acetate) radiates from the $\mathrm{CrO}_{6}$-core to form a distorted octahedron with $D_{3}$ symmetry. The ligands carboxylate persuade a minor average bite angle $(<\mathrm{O}-\mathrm{Cr}-\mathrm{O}$ $=65^{\circ}$ ) and lead to bending of the average axial O-Cr-O bond angle to $162^{\circ}$ [16]. Furthermore, the typical carboxylate $\mathrm{O}-\mathrm{C}-\mathrm{O}$ bond angle $\left(116^{\circ}\right)$ is abridged from that of the free acetate ion $\left(128.83^{\circ}\right)$ [33].

Table 1. Structural parameters of the free acetate and tris(acetate) complex of $\mathrm{Cr}$ (III) and $\mathrm{Cr}(\mathrm{VI})$ complexes. The Cr-O bond lengths $\left(d_{\mathrm{Cr}-\mathrm{O}^{\prime}}{ }^{\prime} s\right)$, C-O bond lengths $\left(d_{\mathrm{CO}^{\circ} s}\right)$ and the $\mathrm{O}-\mathrm{Cr}-\mathrm{O}$ bending angles $\left(\theta_{\mathrm{O}-\mathrm{Cr}-\mathrm{O}} s\right)$, the C-C-O bending angles $\left(\theta_{\mathrm{CCO}} s\right)$ and $\mathrm{Cr}-\mathrm{O}-\mathrm{C}$ bending angles $\left(\theta_{\mathrm{Cr}-\mathrm{O}-\mathrm{C} S} s\right)$ are presented for trivalent and hexavalent metal ion. The average values with standard deviations in parentheses are listed.

\begin{tabular}{cccc}
\hline Labels & Free acetate & $\operatorname{Tris}\left[\mathrm{Cr}^{\mathrm{III}}(\mathrm{AC})_{3}\right]^{0}$ & $\left.\operatorname{Tris}^{0} \mathrm{Cr}^{\mathrm{VI}}(\mathrm{AC})_{3}\right]^{3+}$ \\
\hline $\mathrm{C}_{\text {carbox }}-\mathrm{C}_{(\text {chain })}$ & 1.558 & 1.493 & 1.430 \\
$\mathrm{Cr}^{-} \mathrm{O}_{\text {carbox }}$ & & $2.01(1.98)^{\mathrm{a}}(2.008)^{\mathrm{b}}$ & 1.85 \\
$\mathrm{O}-\mathrm{O}_{\text {intra }}$ & 2.256 & 2.163 & 2.051 \\
$\mathrm{Cr}^{-} \mathrm{C}_{\text {carbox }}$ & & 2.355 & 2.358 \\
$\mathrm{O}-\mathrm{O}_{\text {inter }}$ & & 2.934 & 2.778 \\
$\mathrm{O}-\mathrm{O}_{\text {inter }}$ & & 3.961 & 3.526 \\
$\mathrm{C}_{\text {carbox }}-\mathrm{O}$ & 1.251 & 1.269 & 1.318 \\
$<\mathrm{O}-\mathrm{Cr}-\mathrm{O}$ & & $90.58( \pm 15.64)$ & $90.75( \pm 18.14)$ \\
$<\mathrm{O}-\mathrm{C}-\mathrm{O}$ & $128.83(123)^{\mathrm{c}}$ & 116.83 & 103.23 \\
$<\mathrm{Cr}-\mathrm{O}-\mathrm{C}$ & & 88.98 & 94.55 \\
$<\mathrm{C}-\mathrm{C}-\mathrm{O}$ & 115.18 & $121.58( \pm 0.18)$ & $128.38( \pm 3.63)$ \\
\hline
\end{tabular}

${ }^{\mathrm{a}}$ Ref. [5], ${ }^{\mathrm{b}}$ Ref. [9], ${ }^{\mathrm{c}}$ Ref. [40]. 


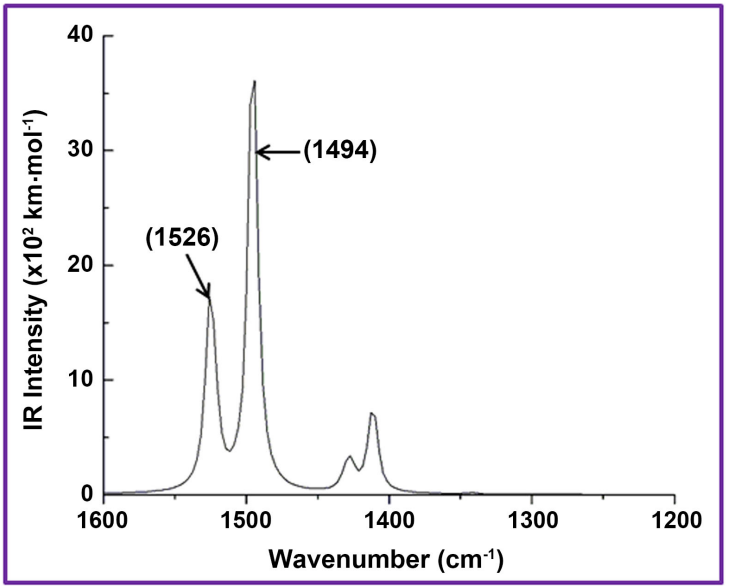

Figure 2. IR spectrum of the tris $\left[\mathrm{Cr}^{\mathrm{III}}(\mathrm{AC})_{3}\right]^{0}$ compound. The two major strongest peaks are shown by the arrows.

FT-IR is one of the well-established diagnostic probes of carboxylate coordination in metal complexes. The difference in wavenumbers between the antisymmetric and symmetric $\mathrm{CO}_{2}$ stretches $(\Delta)$ distinguishes between monodentate and free ion $\left(>200 \mathrm{~cm}^{-1}\right)$, bridging $\left(200-100 \mathrm{~cm}^{-1}\right)$ and bidentate $\left(<100 \mathrm{~cm}^{-1}\right)$ carboxylate bonding geometries [31].

The IR spectra of tris chromium acetate complex $\left[\mathrm{Cr}^{\mathrm{III}}(\mathrm{AC})_{3}\right]^{0}$ are shown in Figure 2. The scaled wavenumbers of free carboxylate (acetate), tris-chromium acetate complexes $\left[\mathrm{Cr}(\mathrm{AC})_{3}\right]^{n}$ (where $n=0,+3$ ) of are reported in Table 2. These data demonstrates the antisymmetric $\left(v_{\text {asym }}^{\text {COO }}\right)$ stretch at $1526 \mathrm{~cm}^{-1}$ and the symmetric ( $v_{\text {sym }}^{\mathrm{COO}}$ ) stretch in the $\sim 1494 \mathrm{~cm}^{-1}$ region yielding a respective separation $\left(\Delta v_{a-s}=v_{\text {asym }}^{\mathrm{COO}}-v_{\text {sym }}^{\mathrm{COO}}\right)$ is $\sim 32 \mathrm{~cm}^{-1}$ of tris $\left[\mathrm{Cr}^{\mathrm{III}}(\mathrm{AC})_{3}\right]^{0}$ complex. The presence of more than one band which may be assigned to (COO ) vibrations suggests that the three carboxylate groups are non-equivalent. These two leading infrared (IR) peaks are close in frequency to those previously calculated and experimental data observed for tris-chromium carboxylates complex $\mathrm{Cr}^{\mathrm{III}}(\mathrm{EH})_{3}$ at 1515 and $1455 \mathrm{~cm}^{-1}$ respectively [16]. These data support carboxylate as bidentate coordination with the chromium centre [16]. This suggests the hexacoordination [15] of chromium provided one of the acetate groups is asymmetric with one $\mathrm{Cr}-\mathrm{O}$ bond is normal and other significantly longer. All the ${ }^{\circ} \mathrm{CO}_{2}$ stretches was assigned supported by the computational modeling. The IR peaks with high intensities arose from the large charge polarization since the positive $\mathrm{Cr}(\mathrm{III})$ ion being en-closed by three negatively charged acetate ligands. Due to charge polarization, the vibrations that result in unsymmetrical distortions convince large dipole moment deviations and large IR intensities. Table 2 reports the vibrational normal modes allied with the bidentate carboxylate groups and their distinctive absorptions reflect the dissimilarities in molecular structure of $\mathrm{Cr}$-acetate complex. The assignment of the theoretically calculated frequencies is based on the experimentally observed band frequencies and intensities in the IR spectra [15]. The monomer bidentate structure $\left[\mathrm{Cr}^{\mathrm{III}}(\mathrm{AC})_{3}\right]^{0}$ demonstrates good harmony with the experimental infrared spectra. 
Table 2. The vibrational frequencies and assignments associated with the $\mathrm{CO}_{2}$ group of the optimized tris chromium acetate $\left[\mathrm{Cr}^{\mathrm{III}}(\mathrm{AC})_{3}\right]^{0}$ complex at the level of DFT/wB97XD/6$311++G(d, p)$.

\begin{tabular}{ccc}
\hline Frequencies $\left(\mathrm{cm}^{-1}\right)$ & Experimental & DFT Calculation (present study) \\
\hline$v_{\text {anyisym }}$ & ${ }^{\mathrm{a}} 1515$ & $1526,1525\left({ }^{\mathrm{b}} 1510-1527\right)$ \\
$v_{\text {sym }}$ & ${ }^{\mathrm{a}} 1455$ & $1494\left({ }^{\mathrm{b}} 1452-1464\right)$ \\
$\Delta v_{a-s}$ & $\sim 60$ & $\sim 32\left(\sim^{\mathrm{b}} 60\right)$ \\
\hline
\end{tabular}

${ }^{\mathrm{a}, \mathrm{b}}$ experimentally and theoretically calculated frequencies by sydaro et al. [16].

\subsection{Binding Energy Analysis}

The binding energies $(\Delta E)$ are correlated with the stability of the corresponding complexes. This elucidates that the stability of the complexes in gas phase escalations with the increasing absolute binding energy. The binding energies $(\Delta E)$, enthalpies $(\Delta H)$ and Gibbs free energies $(\Delta G)$ of tris chromium acetate complexes with different oxidation states and spin states were calculated and summarized in Table 3. Electronic energies only included for the calculation of above $\Delta E$ s binding energies. Because of the covalent nature of the metal ligand bindings, the vibrational, thermal and entropic contributions to $\Delta E$ turned out to be insignificant. According to Table 3, the calculated binding energies trend at differentoxidation states are as follows: $\mathrm{Cr}(\mathrm{VI})>\mathrm{Cr}(\mathrm{V})>\mathrm{Cr}(\mathrm{IV})>\mathrm{Cr}(\mathrm{III})>$ $\mathrm{Cr}(\mathrm{II})>\mathrm{Cr}$ (I). This trend shows that carboxylate (AC) has a higher probability of selective complexation with $\mathrm{Cr}(\mathrm{VI})$. But the other oxidation states like $\mathrm{Cr}(\mathrm{V})$, $\mathrm{Cr}(\mathrm{IV}), \mathrm{Cr}(\mathrm{II})$ and $\mathrm{Cr}(\mathrm{I})$ complexes are not stable. These complexes with these oxidation states are limited in the environment. The two major oxidation states $\mathrm{Cr}(\mathrm{VI})$ and $\mathrm{Cr}(\mathrm{III})$ predominant in the environment and $\mathrm{Cr}(\mathrm{VI})$ reduced to $\mathrm{Cr}$ (III) under the acidic conditions.

In case of $\mathrm{Cr}$ (III) complexes, the relative energy of low-spin state is higher than high-spin state by $385.79 \mathrm{kcal} \cdot \mathrm{mol}^{-1}$ (see Table 3). Likewise, for Cr (VI) complex the relative energy at low spin state is larger than high spin states by $768.69 \mathrm{kcal} \cdot \mathrm{mol}^{-1}$ respectively. Based on the relative energies of $\mathrm{Cr}(\mathrm{III})$ and $\mathrm{Cr}(\mathrm{VI})$ tris-acetate complexes, it was viewed that the stability of the complexes intensification in the order of HS > LS. Comparing all the estimated binding energy values, it was concluded that $\mathrm{Cr}(\mathrm{VI})$ at high spin state was the most preferable to form the tris chromium-acetate complex. According to Boys-Bernandi counterpoise (CP) [34] corrected method we have checked the basis set superposition error (BSSE) for thetris $\left[\mathrm{Cr}(\mathrm{AC})_{3}\right]^{0}$ and $\left[\mathrm{Cr}(\mathrm{AC})_{3}\right]^{3+}$ complexes of high spin state only. The BSSE-corrected energy $E_{\text {complex }}^{C P}(-1730.06 \mathrm{au})$ is compared with the uncorrected energy $E_{\text {complex }}(-1730.06 \mathrm{au})$. The relative deviation defined as $\left|\left(E_{\text {complex }}-E_{\text {complex }}^{C P}\right) / E_{\text {complex }}\right| \times 100$. The calculated BSSE were within $0.001 \%$ of the complexes energy which was in the range of computational error.

By employing the conductor-like polarizable continuum model (CPCM), [35] [36] [37] we also examined the effects of solvent for the $\mathrm{Cr}(\mathrm{III})$ and $\mathrm{Cr}(\mathrm{VI})$ tris acetate complexes. The estimated energy of each complex was almost unaffected 
Table 3. Calculated spin states metal-ligand binding energies, $\Delta E$, relative energies, enthalpies and Gibbs free energies $\Delta G$ for different oxidation states. The binding energies were amended by applying thermodynamics conditions, $298.15 \mathrm{~K}$ and $1 \mathrm{~atm}$. The units of energies are $\mathrm{kcal} \cdot \mathrm{mol}^{-1}$.

\begin{tabular}{|c|c|c|c|c|c|}
\hline \multirow{3}{*}{$\mathrm{Cr}(\mathrm{I})$} & doublet & -54.20 & 10.32 & -53.09 & -52.10 \\
\hline & quartet & -63.81 & 0.71 & -63.21 & -52.14 \\
\hline & sextet & -64.52 & 0 & -63.12 & -41.41 \\
\hline \multirow{3}{*}{$\mathrm{Cr}(\mathrm{II})$} & singlet & -69.50 & 127.30 & -195.70 & -183.00 \\
\hline & triplet & -77.64 & 119.16 & -203.92 & -192.46 \\
\hline & quintet & -196.80 & 0 & -195.31 & -183.88 \\
\hline \multirow[b]{2}{*}{$\mathrm{Cr}(\mathrm{III})$} & doublet & -66.12 & 385.79 & -441.73 & -438.22 \\
\hline & quartet & $\begin{array}{c}-451.91 \\
(-451.18)^{\mathrm{a}}\end{array}$ & 0 & -449.87 & -429.94 \\
\hline \multirow{2}{*}{$\mathrm{Cr}(\mathrm{IV})$} & singlet & 7.60 & 768.69 & -747.68 & -747.66 \\
\hline & triplet & -761.09 & 0 & -759.22 & -735.66 \\
\hline $\mathrm{Cr}(\mathrm{V})$ & doublet & -1173.54 & & -1172.18 & -1160.34 \\
\hline $\mathrm{Cr}(\mathrm{VI})$ & singlet & -1721.07 & & -1720.6 & -1708.52 \\
\hline
\end{tabular}

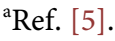

in water solvent, only fluctuating by less than $0.008 \%$. Due to the presence of the solvent, the structural change of each complex was not considered in this calculation. We however guess that the near-octahedron geometry around the central metal of each compound rests approximately unbroken with the introduction of the solvent. Thus, the binding energies of metal-ligand apparently will not fluctuate far from those in the solvent.

Due to the upturn of the amount of the precise interchange energy, high spin state with higher number of unpaired electrons is strongly stabilized compared to the low spin states. Thus energy investigation displays that the smaller ionic radius with more charge like $\mathrm{Cr}(\mathrm{VI})$, and the shorter bond distances $\mathrm{M}-\mathrm{O}(\mathrm{Cr}-\mathrm{O}$, $1.85 \AA$ ) allows the metal ion to withdraw more electron density from the carboxylates. These outcomes lead to the increase the charge transfer among the acetate (AC) and chromium metal ions. Furthermore, binding enthalpy $\left(\Delta H_{\text {bind }}\right)$ of coordination shows that the interactions between carboxylate and chromium ions are affected by the thermal correction in water. It is noticed that complexes with the same ligand acetate, $\mathrm{Cr}$ (VI) is more stable compare to the $\mathrm{Cr}$ (III). Thus a correlation is noticed between the complexation capacity and size of the metal ions, because the metal-ligand fascination proves to be the opposite of the ionic radius. Therefore, these results are reliable with the difference in size among the ions, 0.76 [38] and $0.44^{\circ} \mathrm{A}$ [39] for $\mathrm{Cr}$ (III) and $\mathrm{Cr}(\mathrm{VI})$, respectively.

\subsection{Spectroscopic Data}

The theoretical absorption spectrum of tris $\left[\mathrm{Cr}^{\mathrm{III}}(\mathrm{AC})_{3}\right]^{0}$ complex was calculated 
using Gaussian16 program package at DFT level using the optimized lowest energy structure. Figure 3 illustrates the UV-vis absorption spectrum of the tris $\left[\mathrm{Cr}^{\mathrm{III}}(\mathrm{AC})_{3}\right]^{0}$ complex. The calculated wavelength, oscillatory strength and excitation energy of tris $\left[\mathrm{Cr}^{\mathrm{III}}(\mathrm{AC})_{3}\right]^{0}$ complex was tabulated in Table 4. Two major strong peaks were witnessed at $420 \mathrm{~nm}$ and $528 \mathrm{~nm}$. The absorption maximum was placed at $528 \mathrm{~nm}$, supportive by the experimental wavelength $(600 \mathrm{~nm})$ of the leading peak originate from tris $\left[\mathrm{Cr}^{\mathrm{III}}(\mathrm{AC})_{3}\right]^{0}$. The calculated wavelength of the studied complex are supportive by the experimental wavelengths at $448 \mathrm{~nm}$ and $600 \mathrm{~nm}$ originated from tris(methacrolato) chromium(III) [16]. The calculated wavelengths are also supportive the experiment done by Valencia-Centeno et al. at $416 \mathrm{~nm}$ and $576 \mathrm{~nm}$ [40]. Therefore, this results are in agreement with the established transitions, indicating that in $\mathrm{Cr}\left(\mathrm{O}_{2} \mathrm{CCH}_{3}\right)_{3}$ the chromium ion exhibits an oxidation state of III and an octahedral coordination sphere. To illustrate the electronic transitions, six frontier molecular orbitals (MOs) were shown, extending from the highest occupied MO-2(HOMO-2) to the lowest unoccupied MO+1 (LUMO+1) (Figure 4). The absorption maximum at $528 \mathrm{~nm}$ arose mostly from the HOMO to LUMO transition. The electron density in the HOMO is mostly disseminated over the three acetate ligands. The formation of

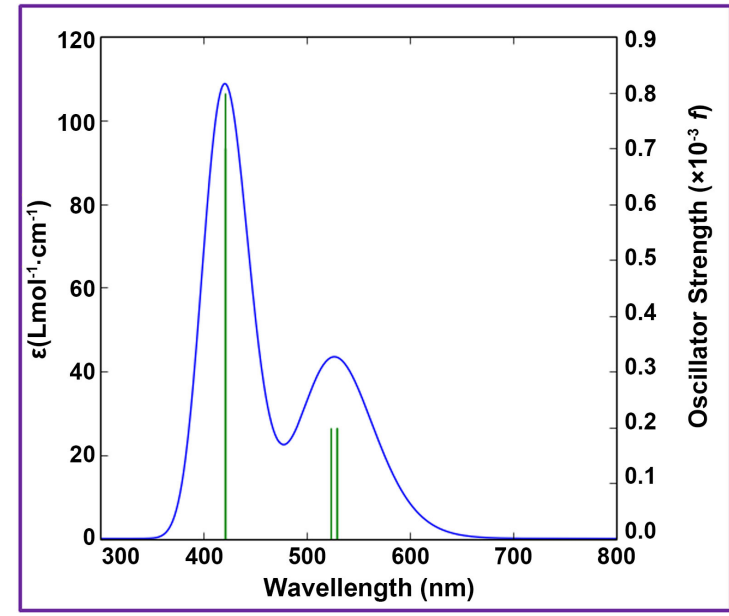

Figure 3. UV-vis spectrum of the tris $\left[\mathrm{Cr}^{\mathrm{III}}(\mathrm{AC})_{3}\right]^{0} \mathrm{com}$ plex calculated from the present calculation.

Table 4. Calculated wavelength, oscillatory strength and excitation energy of tris $\left[\mathrm{Cr}^{\mathrm{III}}(\mathrm{AC})_{3}\right]^{0}$ complex.

\begin{tabular}{ccccc}
\hline Wave length $(\mathrm{nm})$ & $\mathrm{E}(\mathrm{eV})$ & $f$ (oscillator strength) & Major contributions & Assignments \\
\hline $528.78(600)^{\mathrm{a}}(576)^{\mathrm{b}}$ & 2.34 & 0.0002 & $\mathrm{H} \rightarrow \mathrm{L}(39 \%), \mathrm{H}-1 \rightarrow \mathrm{L}(19 \%)$ & MLCT/LLCT \\
528.24 & 2.35 & 0.0002 & $\mathrm{H} \rightarrow \mathrm{L}+1(37 \%), \mathrm{H}-1 \rightarrow \mathrm{L}+1(15 \%)$ & MLCT/LLCT \\
523.29 & 2.37 & 0.0002 & $\mathrm{H}-2 \rightarrow \mathrm{L}+1(40 \%), \mathrm{H}-1 \rightarrow \mathrm{L}(23 \%)$ & MLCT/LLCT \\
420.72 & 2.95 & 0.0007 & $\mathrm{H} \rightarrow \mathrm{L}(37 \%), \mathrm{H}-2 \rightarrow \mathrm{L}(12 \%), \mathrm{H}-1 \rightarrow \mathrm{L}+1(12 \%)$ & $\mathrm{MLCT} / \mathrm{LLCT}$ \\
$420.30(448)^{\mathrm{a}}(416)^{\mathrm{b}}$ & 2.95 & 0.0008 & $\mathrm{H} \rightarrow \mathrm{L}+1(40 \%), \mathrm{H}-1 \rightarrow \mathrm{L}(12 \%), \mathrm{H}-2 \rightarrow \mathrm{L}+1(11 \%)$ & $\mathrm{MLCT} / \mathrm{LLCT}$ \\
407.38 & 3.04 & 0.0 & $\mathrm{H}-2 \rightarrow \mathrm{L}(33 \%), \mathrm{H}-1 \rightarrow \mathrm{L}+1(32 \%)$ & MLCT/LLCT \\
\hline
\end{tabular}

${ }^{\text {a}}$ Ref. [16], ${ }^{\text {Ref. [40]. }}$ 


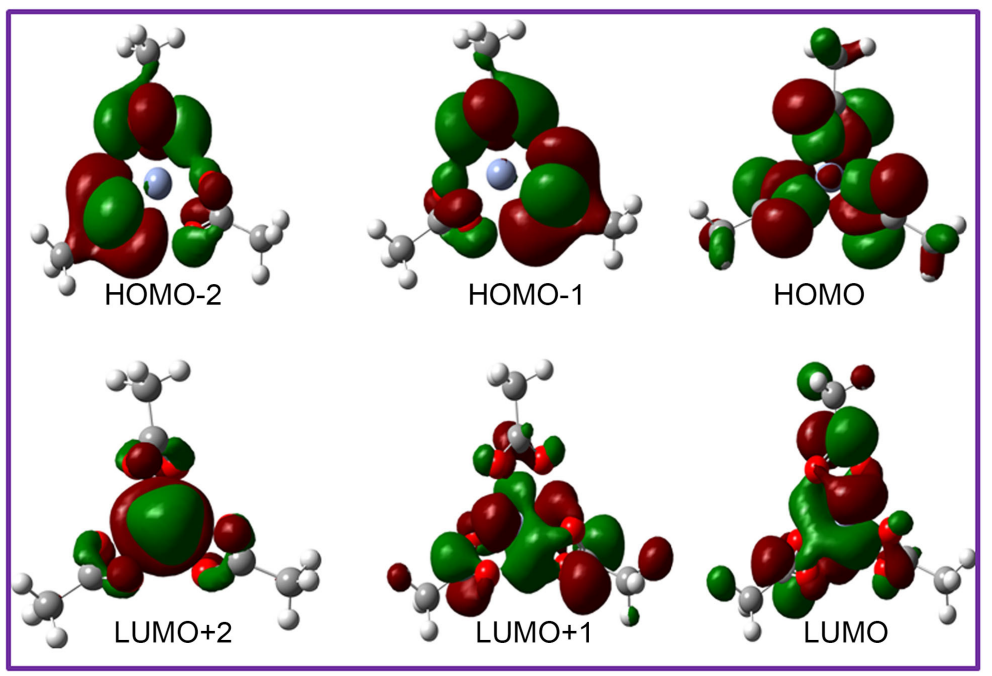

Figure 4. Frontier MOs of the tris chromium acetate $\left[\mathrm{Cr}^{\mathrm{III}}(\mathrm{AC})_{3}\right]^{0}$ complex. The $\mathrm{H}, \mathrm{C}$ and $\mathrm{O}$ atoms are presented as white, gray and red spheres respectively. The orbital lobes presented in green and red represent the opposite phases.

HOMO orbital is primarily owing to $62 \%$ contribution from the chromium iron. In the LUMO presented in Figure 4, however, the electron density is mostly moved out of the acetates into the chromium ion. Thus, the strongest peak of the tris acetate complex in the UV-vis spectrum created obviously from ligand-to-metal $(\mathrm{L} \rightarrow \mathrm{M})$ charge transfer. The peak at $420 \mathrm{~nm}$ mainly (66\%) involved the transition from HOMO to LUMO+1. The orbital illustration of LUMO+1 has likewise the similar type of configuration leading the major involvement of oxygen has $62.89 \%$ contribution for the construction of LUMO+1 orbital. Again, this peak originated from the ligand-to-metal charge transfer; the electron density in HOMO is dispersed mostly over acetate ligands. The contribution of electron density from metal ion has only $7.1 \%$. The peaks located at 420 and 528 $\mathrm{nm}$ arose mostly from the HOMO to LUMO+1 and HOMO to LUMO transitions correspondingly. The HOMO-1 is alike to the HOMO-2 in that the electron density is extended over acetate ligands. The LUMO+1 is alike to the LUMO in that electron density is contained round the metal-oxygen interaction area. Another is that LUMO+1 does not have $\pi$ character of the LUMO orbital.

\subsection{Atomic Charges}

The atomic charges on the metal ions were checked and reported in Table 5. Six different schemes were applied to estimate the charges: the schemes are natural population analysis (NPA), [41] Merz-Singh-Kollman(MK), [42] CHelpG, [43] CHelp [44] methods to fit the electrostatic potential, and the charge fitting method, HLYGAt [45] and NBO [18] [19]. The atomic charges varied from different charge schemes. Such as, the charge at NPA is 1.203 for $\mathrm{Cr}$, whereas the charge was 1.502 if the MK scheme was applied. Generally, the atomic charges 
Table 5. Atomic charges on the metal ion obtained applying different charge schemes, NPA, MK, CHelpG, CHelp, HLYGAt and NBO.

\begin{tabular}{ccccccc}
\hline \multicolumn{7}{c}{ Atomic charges } \\
\hline metal & ${ }^{\mathrm{a}} \mathrm{NPA}$ & ${ }^{\mathrm{b}} \mathrm{MK}$ & ${ }^{\mathrm{c}}$ CHelpG & ${ }^{\mathrm{d}}$ CHelp & HLYGAt & NBO \\
\hline $\mathrm{Cr}^{\mathrm{III}}$ & 1.203 & 1.502 & 1.559 & 1.600 & 1.503 & 1.203 \\
$\mathrm{Cr}^{\mathrm{VI}}$ & 0.954 & 1.128 & 1.178 & 1.232 & 1.232 & 0.955 \\
\hline
\end{tabular}

${ }^{a}$ Natural Population Analysis (NPA) [41]; ${ }^{b} \mathrm{MK}$ (Merz-Singh-Kollman) [42]; 'CHelpG (CHarges from Electrostatic Potentials using a Grid based method) [43]; ${ }^{\mathrm{d}} \mathrm{CHelp}$ methods to fit the electrostatic potential method [44].

decrease with enlarging nuclear charges. The calculated results indicate the more reactivity and stability of tris $\left[\mathrm{Cr}^{\mathrm{VI}}(\mathrm{AC})_{3}\right]^{3+}$ complex compare to $\left[\mathrm{Cr}^{\mathrm{III}}(\mathrm{AC})_{3}\right]^{0}$. The charges on $\mathrm{Cr}(\mathrm{VI})$ in tris $\left[\mathrm{Cr}^{\mathrm{VI}}(\mathrm{AC})_{3}\right]^{3+}$ complex are smaller than $\mathrm{Cr}(\mathrm{III})$ ion in $\left[\mathrm{Cr}^{\mathrm{III}}(\mathrm{AC})_{3}\right]^{0}$.

\subsection{Natural Bond Orbitals Analysis (NBO)}

The natural bond orbital (NBO) analysis [18] [19] was carried out using NBO 3.1 program implemented in the Gaussian 16 to calculate the energy eigenvalues of the frontier molecular orbital ( $\left.\Delta E_{\mathrm{LUMO}-\triangle \text { вномо }}\right)$ energies. The $\mathrm{NBO}$ analyses provide information approximately the electronic structure of a complex. The interactions between the occupied and vacant orbitals signify the deviation of the molecules from the Lewis structure, and the relevant energies can be used as a measure of structure stability.

The donor-acceptor interactions strength, $E_{i j}^{(2)}$ are deduced from the secondorder perturbation theory analysis of the Fock-Matrix [46]. For each donor (i) and $(j)$ acceptor in the complexes, the stabilization energy or second order perturbation energy, associated with the delocalization from was estimated as follows (2).

$$
\Delta E_{i j}^{(2)}=-q \frac{\left(\hat{F}_{i j}\right)^{2}}{\varepsilon_{j}-\varepsilon_{i}}
$$

where $q$ refers to the donor orbital occupancy, $\varepsilon_{i}$ and $\varepsilon_{j}$ are diagonal elements (orbital energies) and $\hat{F}_{i j}$ is the off-diagonal NBO Fock-matrix element. The higher the value of $E_{i j}^{(2)}$, the more the inter-molecular orbital interactions and consequently greater the charge transfer between the donors electron and acceptors which leads to complex stability and stronger metal-binding.

Second-order perturbation energies of interaction $E_{i j}^{(2)}$ were estimated and reported the main interactions in Table 6. The most significant energies are associated with the interactions among the lone pair electrons (oxygen atom) of the ligand $\left(\mathrm{LP}_{\mathrm{O}}\right)$ and anti-bonding orbital of the chromium metal ion $\left(\mathrm{LP}_{\mathrm{M}}^{*}\right)$. A greater donor-acceptor interaction indicates a higher corresponding values and the more efficient charge transfer from the ligand (oxygen atom) to the metal ion (acceptor). According to Table 6, the calculated value for the $\left[\mathrm{Cr}^{\mathrm{III}}(\mathrm{AC})_{3}\right]^{0}$ 
Table 6. Calculated interactions energy $E_{i j}^{(2)} \quad\left(\mathrm{kcal} \cdot \mathrm{mol}^{-1}\right)$ of the metal-acetate tris $\left[\mathrm{Cr}{ }^{\mathrm{III}}(\mathrm{AC})_{3}\right]^{0}$ and $\left[\right.$ tris $\left[\mathrm{Cr}^{\mathrm{VI}}(\mathrm{AC})_{3}\right]^{3+}$ complexes in gas phase at the DFT/wB97XD/6-311++G(d,p) level of theory.

\begin{tabular}{cccc}
\hline $\begin{array}{c}\text { Donor }(i)-\operatorname{Acceptor}(j) \\
\text { interaction }\left[\mathrm{Cr}\left(\mathrm{II}(\mathrm{AC})_{3}\right]^{0}\right.\end{array}$ & $\begin{array}{c}E_{i j}^{(2)} \\
\left(\mathrm{kcal} \cdot \mathrm{mol}^{-1}\right)\end{array}$ & $\begin{array}{c}\text { Donor }(i)-\operatorname{Acceptor}(j) \\
\text { interaction }\left[\mathrm{Cr}^{\mathrm{VI}}(\mathrm{AC})_{3}\right]^{3+}\end{array}$ & $\begin{array}{c}E_{i j}^{(2)} \\
\left(\mathrm{kcal} \cdot \mathrm{mol}^{-1}\right)\end{array}$ \\
\hline $\mathrm{LP}_{\mathrm{O} 1} \rightarrow \mathrm{LP}_{\mathrm{Cr}}^{*}$ & 6.07 & $\mathrm{LP}_{\mathrm{O} 1} \rightarrow \mathrm{LP}_{\mathrm{Cr}}^{*}$ & 14.35 \\
$\mathrm{LP}_{\mathrm{O} 2} \rightarrow \mathrm{LP}_{\mathrm{Cr}}^{*}$ & 6.09 & $\mathrm{LP}_{\mathrm{O} 2} \rightarrow \mathrm{LP}_{\mathrm{Cr}}^{*}$ & 17.34 \\
$\mathrm{LP}_{\mathrm{O} 3} \rightarrow \mathrm{LP}_{\mathrm{Cr}}^{*}$ & 6.07 & $\mathrm{LP}_{\mathrm{O} 3} \rightarrow \mathrm{LP}_{\mathrm{Cr}}^{*}$ & 14.48 \\
$\mathrm{LP}_{\mathrm{O} 4} \rightarrow \mathrm{LP}_{\mathrm{Cr}}^{*}$ & 6.11 & $\mathrm{LP}_{\mathrm{O} 4} \rightarrow \mathrm{LP}_{\mathrm{Cr}}^{*}$ & 17.39 \\
$\mathrm{LP}_{\mathrm{O} 5} \rightarrow \mathrm{LP}_{\mathrm{Cr}}^{*}$ & 6.11 & $\mathrm{LP}_{\mathrm{O} 5} \rightarrow \mathrm{LP}_{\mathrm{Cr}}^{*}$ & 17.25 \\
$\mathrm{LP}_{\mathrm{O} 6} \rightarrow \mathrm{LP}_{\mathrm{Cr}}^{*}$ & 6.07 & $\mathrm{LP}_{\mathrm{O} 6} \rightarrow \mathrm{LP}_{\mathrm{Cr}}^{*}$ & 17.14 \\
& $\sum E_{i j}^{(2)}=36.52$ & & $\sum E_{i j}^{(2)}=97.95$ \\
\hline
\end{tabular}

complex $\left(36.52 \mathrm{kcal} \cdot \mathrm{mol}^{-1}\right)$ is less significant than that of hexavalent tris chromium acetate $\left[\mathrm{Cr}^{\mathrm{VI}}(\mathrm{AC})_{3}\right]^{3+}$ complex $\left(96.95 \mathrm{kcal} \cdot \mathrm{mol}^{-1}\right)$. This supports the stronger interaction of the carboxylate and $\mathrm{Cr}(\mathrm{VI})$, that is according to the energy analysis. Comparing the calculated values of $\Delta E_{\text {bind }}$ in Table 3 and in Table 6 shows a correlation. In additional, an increase in values is followed by the increment of $\Delta E_{\text {bind }}$ values.

\subsection{Quantum Chemistry Reactivity Indices}

To know the chemical stability of a complex, it needs the information of quantum chemistry reactivity indices like a high HOMO-LUMO energy gap, ionization potential, electron affinity, chemical hardness etc. Molecules are classified as hard and soft based on the calculated HOMO-LUMO energy gap value. Soft molecules have lower energy gap comparing to hard one and are more polarizable due to their small energy of excitation. Based on calculated HOMO and LUMO energies, the ionization potential $(I)$ and electron affinity $(A)$ are calculated using the subsequent equations $I=-E_{\text {Номо }}$ and $A=-E_{\mathrm{LUMO}}$. Thus, the electronegativity and chemical hardness are calculated applying $\chi=(I+A) / 2$ and $\eta=(I-A) / 2$. The chemical potential and chemical softness are estimated as the negative of electronegativity $(\mu=-\chi)$ and inverse of hardness $(S=1 / \eta)$, respectively. Using the electronic chemical potential, $\mu$ and chemical hardness, $\eta$ the global electrophilicity index $\omega$ was calculated by the equation (Equation (3))

$$
\omega=\frac{\mu^{2}}{2 \eta}
$$

The calculated quantum chemistry reactivity indices are reported in Table 7. In these calculations tris $\left[\mathrm{Cr}^{\mathrm{III}}(\mathrm{AC})_{3}\right]^{0}$ complex considered as hard as compared to tris $\left[\mathrm{Cr}^{\mathrm{VI}}(\mathrm{AC})_{3}\right]^{3+}$ complex. During the complex formation of tris $\left[\mathrm{Cr}^{\mathrm{VI}}(\mathrm{AC})_{3}\right]^{3+}$ the electronic chemical hardness $(\eta)$ and electronic chemical potential $(\mu)$ decreases while electronegativity increases. The chemical hardness decrease will lead 
Table 7. HOMO, LUMO and electronic parameters analysis of the free carboxylate (acetate), tris chromium acetate $\left[\mathrm{Cr}^{\mathrm{III}}(\mathrm{AC})_{3}\right]^{0}$ and $\left[\mathrm{Cr}^{\mathrm{VI}}(\mathrm{AC})_{3}\right]^{3+}$ complexes in the gas phase at theDFT/wB97XD/6-311++G(d,p) level of theory.

\begin{tabular}{cccc}
\hline Chemical reactivity indices & Free acetate & {$\left[\mathrm{Cr}^{\mathrm{III}}(\mathrm{AC})_{3}\right]^{0}$} & {$\left[\mathrm{Cr}^{\mathrm{VI}}(\mathrm{AC})_{3}\right]^{3+}$} \\
\hline$E_{\mathrm{HOMO}}(\mathrm{eV})$ & -3.13 & -10.69 & -25.56 \\
$E_{\mathrm{LUMO}}(\mathrm{eV})$ & 4.35 & 0.41 & -18.26 \\
$E_{\mathrm{g}}(\mathrm{eV})$ & 7.48 & 11.10 & 7.30 \\
Ionization potential $I(\mathrm{eV})$ & 3.13 & 10.69 & 25.56 \\
Electron affinity $A(\mathrm{eV})$ & -4.35 & -0.41 & 18.26 \\
Electronegativity $\chi(\mathrm{eV})$ & -0.61 & 5.14 & 21.91 \\
Chemical hardness $(\eta)$ & 3.74 & 5.55 & 3.65 \\
Chemical potential $(\mu)$ & 0.61 & -5.14 & -21.91 \\
Global electronegativity $(\omega)$ & 0.05 & 2.380 & 66.30 \\
Chemical softness $S(\mathrm{eV})$ & 0.27 & 0.18 & 0.27 \\
\hline
\end{tabular}

to an increase in the chemical stability of the system. The obtained result is also in agreement with the trend of $\Delta E_{\text {Hомо-LUмо }}$ gaps which is also an indicator of chemical stability, i.e., the greater $\Delta E_{\mathrm{HO} о-L u м о ~}$ gap provides less chance for electron excitation and makes the system less reactive. A decrease in the electronic chemical potential of the $\left[\mathrm{Cr}^{\mathrm{VI}}(\mathrm{AC})_{3}\right]^{3+}$ complex in comparison to the $\left[\mathrm{Cr}^{\mathrm{III}}(\mathrm{AC})_{3}\right]^{0}$ specifies an increase in stability.

\section{Conclusion}

In the present study, DFT calculations were conducted to illustrate the complexation of chromium metal at different oxidation states and spin states with carboxylate (acetate) ligand in gas phase. The calculated average $\mathrm{Cr}-\mathrm{O}$ bond lengths in the $\left[\mathrm{Cr}^{\mathrm{III}}(\mathrm{AC})_{3}\right]^{0}$ and $\left[\mathrm{Cr}^{\mathrm{VI}}(\mathrm{AC})_{3}\right]^{3+}$ complexes are $2.01 \AA$ and $1.85 \AA$ respectively which strongly favors the chromium tris $\left[\mathrm{Cr}^{\mathrm{VI}}(\mathrm{AC})_{3}\right]^{3+}$ complex. The current DFT calculations simulated the IR and UV-vis absorption spectra of the tris chromium acetate complexes, which are all consistent with the previous experimental measurements and theoretical calculations. Based on calculations of energy ( $\Delta E$ ), enthalpy $(\Delta H)$ and Gibbs free energy $(\Delta G)$, tris $\left[\mathrm{Cr}^{\mathrm{VI}}(\mathrm{AC})_{3}\right]^{3+}$ complex is the most stable in comparison with other chromium-carboxylate complexes. However, the chemical reactivity indices were calculated based on band gap energy. The charge calculations show that in tris $\left[\mathrm{Cr}^{\mathrm{VI}}(\mathrm{AC})_{3}\right]^{3+}$ complex, the chromium metal ion withdraws more electrons from oxygen atoms compared to tris $\left[\mathrm{Cr}^{\mathrm{III}}(\mathrm{AC})_{3}\right]^{0}$ complex. Natural population analysis (NBO) specified the basis of these interactions is the lone pair electrons of the oxygen atoms $\left(\mathrm{LP}_{\mathrm{O}}\right)$ and the anti-bonding electron of the chromium metal ion $\left(\mathrm{LP}_{\mathrm{Cr}}{ }^{*}\right)$. Additionally, the interactions are non-covalent, which are associated with the charge transfer from the oxygen to the metal ion center. The quantum chemistry reactivity indices calculation indicates tris $\left[\mathrm{Cr}^{\mathrm{III}}(\mathrm{AC})_{3}\right]^{0}$ complex considered as hard as compared 
to tris $\left[\mathrm{Cr}^{\mathrm{VI}}(\mathrm{AC})_{3}\right]^{3+}$ complex. The outcome of this study provides helpful implications concerning the metal ions and ligand, which can potentially act as a chelating agent.

\section{Acknowledgements}

AM gratefully acknowledges the Centre (CARS), Dhaka University, Dhaka-1000, Bangladesh, for High Performance Computing (HPC) for Computational Modeling and simulation.

\section{Conflicts of Interest}

The authors declare no conflicts of interest regarding the publication of this paper.

\section{References}

[1] Shupack, S.I. (1991) The Chemistry of Chromium and Some Resulting Analytical Problems. Environmental Health Perspectives, 92, 7-11.

https://doi.org/10.1289/ehp.91927

[2] Campbell, J.A. and Whiteker, R.A. (1969) A Periodic Table Based on Potential-pH Diagrams. Journal of Chemical Education, 46, 90-92. https://doi.org/10.1021/ed046p90

[3] Mitewa, M. and Bontchev, P. (1985) Chromium (V) Coordination Chemistry. CoOrdination Chemistry Reviews, 61, 241-272. https://doi.org/10.1016/0010-8545(85)80006-0

[4] Dittert, I.M., Vilar, V.J.P., da Silva, E.A.B., de Souza, S.M.A.G.U., de Souza, A.A.U., Botelho, C.M.S. and Boaventura, R.A.R. (2012) Adding Value to Marine Macro-Algae Laminaria digitata through Its Use in the Separation and Recovery of Trivalent Chromium Ions from Aqueous Solution. Chemical Engineering Journal, 193-194, 348-357. https://doi.org/10.1016/j.cej.2012.04.048

[5] Zheng, Y.-M., Liu, T., Jiang, J., Yang, L., Fan, Y., Wee, A.T.S. and Chen, J.P. (2011) Characterization of Hexavalent Chromium Interaction with Sargassum by X-Ray Absorption Fine Structure Spectroscopy, X-Ray Photoelectron Spectroscopy, and Quantum Chemistry Calculation. Journal of Colloid and Interface Science, 356, 741-748. https://doi.org/10.1016/j.jcis.2010.12.070

[6] Mehandzhiyski, A.Y., Riccardi, E., van Erp, T.S., Koch, H., Åstrand, P.-O., Trinh, T.T. and Grimes, B.A. (2015) Density Functional Theory Study on the Interactions of Metal Ions with Long Chain Deprotonated Carboxylic Acids. Journal of Physical Chemistry A, 119, 10195-10203. https://doi.org/10.1021/acs.jpca.5b04136

[7] Turowski, P.N., Bino, A. and Lippard, S.J. (1990) $\mu$-Hydroxobis ( $\mu$-forma-to)hexaaquadichromium(III), an Intermediate in the Formation of Basic Chromium Carboxylates. Angewandte Chemie International Edition English, 29, 811-812. https://doi.org/10.1002/anie.199008111

[8] Ellis, T., Glass, M., Harton, A., Folting, K., Huffman, J.C. and Vincent, J.B. (1994) Synthetic Models for Low-Molecular-Weight Chromium-Binding Substance: Synthesis and Characterization of Oxo-Bridged Tetranuclear Chromium(III) Assemblies. Inorganic Chemistry, 33, 5522-5527. https://doi.org/10.1021/ic00102a028

[9] Eshel, M., Bino, A., Felner, I., Johnston, D.C., Luban, M. and Miller, L.L. (2000) Poly-Nuclear Chromium (III) Carboxylates. 1. Synthesis, Structure, and Magnetic 
Properties of an Octanuclear Complex with a Ring Structure. Inorganic Chemistry, 39, 1376-1380. https://doi.org/10.1021/ic9907009

[10] Blann, K., Bollmann, A., de Bod, H., Dixon, J.T., Killian, E., Nongodlwana, P., Maumela, M.C., Maumela, H., McConnell, A.E., Morgan, D.H., Overett, M.J., Prétorius, M., Kuhlmann, S. and Wasserscheid, P. (2007) Ethylene Tetramerisation: Subtle Effects Exhibited by N-Substituted Diphosphinoamine Ligands. Journal of Catalysis, 249, 244-249. https://doi.org/10.1016/j.jcat.2007.04.009

[11] Rao, C.N.R., Natarajan, S. and Vaidhyanathan, R. (2004) Metal Carboxylates with Open Architectures. Angewandte Chemie International Edition English, 43, 1466-1496. https://doi.org/10.1002/anie.200300588

[12] Warner, A. (1908) ZurTheorie der Beizenfarbstoffe. Berichte der Deutschen Chemischen Gesellschaft, 41, 2383-2386. https://doi.org/10.1002/cber.190804102149

[13] Kambe, K. (1950) On the Paramagnetic Susceptibilities of Some Polynuclear Complex Salts. Journal of Physical Society Japan, 5, 48-51. https://doi.org/10.1143/JPSJ.5.48

[14] Erre, L.S., Micera, G., Glowiak, T. and Kozlowski, H. (1997) Chromium(III) Acetate, Chromium(III) Acetate Hydroxide, or $\mu 3$-Oxo-esakis-( $\mu 2$-acetato-O,O') Tria-quatrichromium(III) Acetate? Determining the Structure of a Complex Compound by Analytical and Spectroscopic Methods. Journal of Chemical Education, 74, 432. https://doi.org/10.1021/ed074p432

[15] Kapoor, R. and Sharma, R. (1983) Anhydrous Chromium(III) Carboxylates: Reactions of $\mathrm{CrO}_{3}$ with Carboxylic Acid Anhydrides. Zeitschrift für Naturforschung, 38, 42. https://doi.org/10.1515/znb-1983-0110

[16] Sydora, O.L., Hart, R.T., Eckert, N.A., Martinez Baez, E., Clark, A.E. and Benmore, C.J. (2018) A Homoleptic Chromium(III) Carboxylate. Dalton Transactions, 47, 4790-4793. https://doi.org/10.1039/C8DT00029H

[17] Matin, M.A., Mazharul, M.I., Bredow, T. and Aziz, M.A. (2017) The Effects of Oxidation States, Spin States and Solvents on Molecular Structure, Stability and Spectroscopic Properties of Fe-Catechol Complexes: A Theoretical Study. Advances in Chemical Engineering and Science, 7, 137-153. https://doi.org/10.4236/aces.2017.72011

[18] Foster, J.P. and Weinhold, F. (1980) Natural Hybrid Orbitals. Journal American Chemical Society, 102, 7211-7218. https://doi.org/10.1021/ja00544a007

[19] Reed, A.E. and Weinhold, F. (1983) Natural Bond Orbital Analysis of Near-HartreeFock Water Dimer. Journal of Chemical Physics, 78, 4066-4073. https://doi.org/10.1063/1.445134

[20] Pearson, R.G. (1993) The Principle of Maximum Hardness. Accounts of Chemical Research, 26, 250-255. https://doi.org/10.1021/ar00029a004

[21] Pearson, R.G. (1992) The Electronic Chemical Potential and Chemical Hardness. Journal of Molecular Structure: THEOCHEM, 255, 261-270. https://doi.org/10.1016/0166-1280(92)85014-C

[22] Parr, R.G., Szentpály, L.V. and Liu, S. (1999) Electrophilicity Index. Journal of American Chemical Society, 121, 1922-1924. https://doi.org/10.1021/ja983494x

[23] Chai, J.-D. and Head-Gordon, M. (2008) Long-Range Corrected Hybrid Density Functionals with Damped Atom-Atom Dispersion Corrections. Physical Chemistry Chemical Physics, 10, 6615-6620. https://doi.org/10.1039/b810189b

[24] Rassolov, V.A., Pople, J.A., Ratner, M.A. and Windus, T.L. (1998) 6-31G* Basis Set for Atoms K through Zn. Journal of Chemical Physics, 109, 1223-1229. 
https://doi.org/10.1063/1.476673

[25] Ditchfield, R., Hehre, W.J. and Pople, J.A. (1971) Self-Consistent Molecular-Orbital Methods. IX. An Extended Gaussian-Type Basis for Molecular-Orbital Studies of Organic Molecules. Journal of Chemical Physics, 54, 724-728. https://doi.org/10.1063/1.1674902

[26] Hehre, W.J., Ditchfield, R. and Pople, J.A. (1972) Self-Consistent Molecular Orbital Methods. XII. Further Extensions of Gaussian-Type Basis Sets for Use in Molecular Orbital Studies of Organic Molecules. Journal of Chemical Physics, 56, 2257-2261. https://doi.org/10.1063/1.1677527

[27] Frisch, M.J., Trucks, G.W., Schlegel, H.B., Scuseria, G.E., Robb, M.A., Cheeseman, J.R., Scalmani, G., Barone, V., Petersson, G.A., Nakatsuji, H., Li, X., Caricato, M., Marenich, A.V., Bloino, J., Janesko, B.G., Gomperts, R., Mennucci, B., Hratchian, H.P., Ortiz, J.V., Izmaylov, A.F., Sonnenberg, J.L., Williams-Young, D., Ding, F., Lipparini, F., Egidi, F., Goings, J., Peng, B., Petrone, A., Henderson, T., Ranasinghe, D., Zakrzewski, V.G., Gao, J., Rega, N., Zheng, G., Liang, W., Hada, M., Ehara, M., Toyota, K., Fukuda, R., Hasegawa, J., Ishida, M., Nakajima, T., Honda, Y., Kitao, O., Nakai, H., Vreven, T., Thros-sell, K., Montgomery, J.A., Peralta, J.E., Ogliaro, F., Bearpark, M.J., Heyd, J.J., Brothers, E.N., Kudin, K.N., Staroverov, V.N., Keith, T.A., Kobayashi, R., Normand, J., Raghavacha-ri, K., Rendell, A.P., Burant, J.C., Iyengar, S.S., Tomasi, J., Cossi, M., Millam, J.M., Klene, M., Adamo, C., Cammi, R., Ochterski, J.W., Martin, R.L., Morokuma, K., Farkas, O., Foresman, J.B. and Fox, D.J. (2016) Gaussian 16, Revision B.01. Gaussian, Inc., Wallingford.

[28] Matin, M.A., Chitumalla, R.K., Lim, M., Gao, X. and Jang, J. (2015) Density Functional Theory Study on the Cross-Linking of Mussel Adhesive Proteins. Journal of Physical Chemistry B, 119, 5496-5504. https://doi.org/10.1021/acs.jpcb.5b01152

[29] Spellmeyer, D.C. (2005) Annual Reports in Computational Chemistry. Elsevier, Amsterdam.

[30] Yanai, T., Tew, D.P. and Handy, N.C. (2004) A New Hybrid Exchange-Correlation Functional Using the Coulomb-Attenuating Method (CAM-B3LYP). Chemical Physics Letters, 393, 51-57. https://doi.org/10.1016/j.cplett.2004.06.011

[31] Sutton, C.C.R., da Silva, G. and Franks, G.V. (2015) Modeling the IR Spectra of Aqueous Metal Carboxylate Complexes: Correlation between Bonding Geometry and Stretching Mode Wavenumber Shifts. Chemistry—A European Journal, 21, 6801-6805.

https://doi.org/10.1002/chem.201406516

[32] Deacon, G.B. and Phillips, R.J. (1980) Relationships between the Carbon-Oxygen Stretching Frequencies of Carboxylato Complexes and the Type of Carboxylate Coordination. Coordination Chemistry Reviews, 33, 227-250. https://doi.org/10.1016/S0010-8545(00)80455-5

[33] Hsu, L.-Y. and Nordman, C.E. (1983) Structures of Two Forms of Sodium Acetate, $\mathrm{Na}^{+} \mathrm{C}_{2} \mathrm{H}_{3} \mathrm{O}_{2}^{-}$. Acta Crystallographica Section C, 39, 690-694.

https://doi.org/10.1107/S0108270183005946

[34] Boys, S.F. and Bernardi, F. (1970) The Calculation of Small Molecular Interactions by the Differences of Separate Total Energies. Some Procedures with Reduced Errors. Molecular Physics, 19, 553-566. https://doi.org/10.1080/00268977000101561

[35] Barone, V. and Cossi, M. (1998) Quantum Calculation of Molecular Energies and Energy Gradients in Solution by a Conductor Solvent Model. Journal of Physical Chemistry A, 102, 1995-2001. https://doi.org/10.1021/jp9716997

[36] Cossi, M., Rega, N., Scalmani, G. and Barone, V. (2003) Energies, Structures, and Electronic Properties of Molecules in Solution with the C-PCM Solvation Model. 
Journal Computational Chemistry, 24, 669-681. https://doi.org/10.1002/jcc.10189

[37] Tomasi, J., Mennucci, B. and Cammi, R. (2005) Quantum Mechanical Continuum Solvation Models. Chemical Review, 105, 2999-3094.

https://doi.org/10.1021/cr9904009

[38] Quintelas, C., Rocha, Z., Silva, B., Fonseca, B., Figueiredo, H. and Tavares, T. (2009) Removal of $\mathrm{Cd}(\mathrm{II}), \mathrm{Cr}(\mathrm{VI}), \mathrm{Fe}(\mathrm{III})$ and $\mathrm{Ni}(\mathrm{II})$ from Aqueous Solutions by an $E$. coli Bio-Film Supported on Kaolin. Chemical Engineering Journal, 149, 319-324. https://doi.org/10.1016/j.cej.2008.11.025

[39] Aksoy and Özer, M.S.U. (2003) Potentiometric and Spectroscopic Studies with Chromium(III) Complexes of Hydroxysalicylic Acid Derivatives in Aqueous Solution. Turkish Journal Chemistry, 27, 667-673.

[40] Valencia-Centeno, Y., Ureña-Núñez, F., Sánchez-Mendieta, V., Morales-Luckie, R.A., López-Castañares, R. and Huerta, L. (2008) Synthesis and Structural Characterization of Tris(methacrylato)chromium(III). Journal of Coordination Chemistry, 61, 1589-1598. https://doi.org/10.1080/00958970701599611

[41] Reed, A.E., Weinstock, R.B. and Weinhold, F. (1985) Natural Population Analysis. Journal of Chemical Physics, 83, 735-746. https://doi.org/10.1063/1.449486

[42] Singh, U.C. and Kollman, P.A. (1984) An Approach to Computing Electrostatic Charges for Molecules. Journal of Computational Chemistry, 5, 129-145.

https://doi.org/10.1002/jcc.540050204

[43] Breneman, C.M. and Wiberg, K.B. (1990) Determining Atom-Centered Monopoles from Molecular Electrostatic Potentials. The Need for High Sampling Density in Formamide Conformational Analysis, Journal of Computational Chemistry, 11, 361-373. https://doi.org/10.1002/jcc.540110311

[44] Chirlian, L.E. and Francl, M.M. (1987) Atomic Charges Derived from Electrostatic Potentials: A Detailed Study. Journal of Computational Chemistry, 8, 894-905. https://doi.org/10.1002/jcc.540080616

[45] Hu, H., Lu, Z. and Yang, W. (2007) Fitting Molecular Electrostatic Potentials from Quantum Mechanical Calculations. Journal of Chemical Theory and Computation, 3, 1004-1013. https://doi.org/10.1021/ct600295n

[46] Reed, A.E., Curtiss, L.A. and Weinhold, F. (1988) Intermolecular Interactions from a Natural Bond Orbital, Donor-Acceptor Viewpoint. Chemical Review, 88, 899-926. https://doi.org/10.1021/cr00088a005 